in insects (halteres, chordotonal organs) are largely concerned in motor or coördinating or balancing functions, and that they "are analogous to the semicireular canals of vertebrates in their functions."

Let us pass on to ask and try to realise what their subjection to the depressing effects of shock (when animals most universally cry out) upon the motor and coördinating functions has meant to animals and the precarious position in which it has placed them in regard to the business of active life-preservation. With the exception of cases where the suppression of these functions throngh shock gave certain helpless animals a cryptic advantage or gave their enemy a repugnant impression of dead food, the evil of the briefest loss or even impairment of motor and coördinating functions would be as great as death itself. And that much of the stress of life-preservation has been from the remotest stages of animal development thrown upon the power of animal organisms to react rapidly against shock is amply illustrated in the phenomena of expressions of excitement. But the most remarkable point to observe from the standpoint of our problem is that animals generally react against shock by way of the increase and accentuation of life-processes in the order of the ir importanoe in the susterance of motor, coördinating, and psychical functioning, the organs of circulation and respiration reacting first, and most emphatically of all, among the viscera. But besides the increase and accentuation of life-processes upon which motor and psychical functions depend in normal conditions, we find animal organisms setting into motion certain nervous and muscular machinery which in normal conditions, apart from shock or excitement, is more or less quiescent. Among this nervous and muscular machinery I trace the vocal and all other sound-producing apparatus of animals.

No one who looks closely into the genesis and comparative anatomy of the organs of sound-production in animals can fail to be impressed with the eagerness, so to speak, with which animals have seized upon any physiological means of developing a sound-producing instrument. Wonderful as are the advantages which the land vertebrates have taken of the opportunities of sound-production presented by their breathing pipe, perhaps some of the invertebrates display still greater wonders in the way they seized on any opportunity of rubbing the hard integuments of wing cases or wings against each other or against the femur for sound-production.

What is the combined significance of these various points? 1. The prerogatives of the organ of audition over motor and psychical functioning. 2. The eagerness of animal organisms to adopt and develop any available means of producing stimuli to influence the orsan of audition. 3 . The fact that the most universal occasion upon which animals use their sounding instruments is on occasion when their motor and psychical functiouing is threatened with suppression by shock.

What is the significance of the further fact that the power of action in the vocal machinery abides with the animal when the higher powers of volition and consciousne:s are lapsed (as under the action of chloroform), or as shown by experiment after the removal of the cerebral hemispheres? Why does the power to cry out abide so strangely with the animal along with the still available centres for equilibration, coördinated movement, and adaptive reaction? I conclude it is because the primary function of the cry $u$ tered in connexion with pain or any shock or excitement, the function for which organs of sound-production were developed, is to convey stimuli to the shocked motor and coördinating nerve centres of the crying animal.

$$
\text { I am, Sirs, yours faithfully, }
$$

Streatham-bill, S.W., Jan. 13th, 1906. J. Donovan.

\section{MODERN MEDICAL EDUCATION.}

\section{To the Editors of THE LANCET.}

SrRS, - I cannot congratulate either "L.S.A." or "A. F. H." upo z their degree of comprehension of the great subject of modern medical education and the latter overstates his case when he says that the medical treatment of disease is not taught in the curriculum at all. They, however, represent a con-ider tble number of medical men in their attempt to belittle the importance of the preliminary subjects (which in

1 Lowne: The Anatomy of the Blow Fly, part r., p. 618. See also Professor Gaskell, Journal of Anatomy and Physiologs, part ii., January, 1902, p. 183. most of the pass examinations are elementary enough in all conscience) and for no other reason than because they do not appear to be of direct commercial value to a man the moment he has "qualified." They appear to forget that the knowledge of these very scientific subjects is the one safeguard against quackery and dangerous experimentation, or against delusive and seductive theories by which the unscientifically trained are readily deceived. They would do away with the bed-rock upon which the student must build all his subsequently to be acquired clinical knowledge during perhaps the next 40 years of his life. In most cases it is his one opportunity for learning pure science and acquiring a scientific habit of thought before he is launched on the endless distractions and exactions of practice and the rest. They would detract from this valuable discipline in order to give more time for picking up some wrinkles from the dispenser. Is it not rather a question of obeying the dictum, "These ought ye to have done and not to leave the other undone," for ye have need of both ? Time is an element in education which cannot be ignored and short cuts to efficiency are not to be trusted.

There are too many medical men of the prescribing chemist variety already, but what we really want is a smaller number of better men who have not been rushed through a course of training but who by a present sacrifice have insured a greater future efficiency. Of course, a good deal depends on the personal factor and those who have a vocation for medicine will not be so slow or so stupid at picking up practical points in every-day practice as "A. F. H." seems to suppose. Lastly, is it not strange, in an age when commerce is looking increasingly to both pure and applied science for both light and profit, to find members of a learned profession asking that their sons should neglect the foundations of preliminary science in order that they may the more quickly earn money by acquiring the habits of the prescribing chemist? I am, Sirs, yours faithfully,

Old Burlington-street, W., Jan. 20th, $1906 . \quad$ A. W. F ULLER.

\section{SANATORIUM TREATMENT FOR TUBER- CULOSIS.}

To the Editors of THE LANCET.

SiRs,-I am glad to see that Dr. Arthur Latham has corrected some of his conclusions on the statistics of con sumption among the upper classes published by Dr. C. J. B. Williams and myself. The quotation he gives from my father's Lumleian lectures in 1862 alludes to some of the cases which at a later date were included in the 1000 cases published in 1870 in the Transactions of the Royal Medical and Chirurgical Society ard in "Pulmonary Consumption," but a vigorous search and much correspondence revealed the existence and well-being of a number of patients who had before passed out of sight and thus the results became more favourable than at first appeared. The cases, it is true, were selected but the grounds of their selection are fully given in our book ${ }^{1}$ and were based more on the desirability of acquiring information of their further progress than on the intentiun of obtaining favcurable resu'ts. A physician sees a large number of patients once, or possibly twice, and after a few months has lost sight of them altogether. What use are such cases for statistical purposes? Unless some such selection is adopted statistics of the upper classes are impossible. Dr. Latham's complaint that he did not find either in my book or my letter the information how long the "well" patients had been capable of following their occupations after treatment had ceased exemplifies the difficulty of settling questions by statistics when the classes of patients compared are quite different. Many of our patients were of the leisured class and had no profession, their occupation being more or less one of amusement. 375 were women, a great proportion of whom had no occupation but home duties. How can one adopt as a criterion in the case of these "capacity for full work" !

As the statistics were drawn up to demonstrate the length of life among consumptives of the upper classes the deaths were separated from the living and the duration of life in each class was calculated, but even by Dr. Latham's method of including the deaths the "well" and "tolerably well" reach a percentage of $57 \cdot 8$, which is rather higher than that of the German sanatoriums ( 31 per cent. to 53 per cent.) as stated by him. Dr. Latham says my "statistics are not 